\title{
Effect of E-Referral and E-Wom on Purchase Intention: An Empirical Study in Indonesia
}

\author{
Ryan Frederick Tanprajna, Jeanne Ellyawati \\ Universitas Atma Jaya Yogyakarta, Indonesia
}

\begin{abstract}
This study aims to analyze the effect of electronic referral (e-referral) and electronic word of mouth (e-WOM) on purchase intentions. Besides, this study also examines the role of brand image as a variable that mediates the effect of e-referral and e-WOM on purchase intention. The sampling method used non-probability sampling with a combined sampling method, purposive sampling, and snowball sampling technique. Data were collected from undergraduate students who have bought and used laptop ASUS brand at various universities in Yogyakarta. Some 300 respondents were recruited using an online and offline survey design with a structured questionnaire. To verify the hypothesis, data were processed using the statistical program SmartPLS. The results of this study found that e-referral and e-WOM has a positive and significant effect on purchase intentions and brand image. Brand image has a positive and significant effect on purchase intention. The study also found that the effect of ereferral on purchase intentions was greater than the effect of e-WOM on purchase intentions The further finding showed that brand image has a complementary partial mediation effect on the relationship between e-referral and e-WOM on purchase intentions. The e-referral variable has a greater total effect than the e-WOM variable. It means that the brand image has a higher mediating effect through e-referral and purchase intentions than through e-WOM and purchase intention.
\end{abstract}

Keyword: brand image; e-referral; e-WOM; Indonesia; purchase intention

\section{Introduction}

Internet is the real outcome of rapid developments in information and technology and has led to the born of the industrial revolution 4.0. The internet changes and simplifies the way people communicate, both at work and in everyday life. The industrial revolution 4.0 has triggered to rise a new approach and concept in the field of marketing known as Marketing 4.0. Marketing 4.0 is a marketing approach that combines and integrates online and offline interactions between companies and consumers (Kotler et al., 2017). This era can be an 


\title{
$11^{\text {th }}$ International Conference on Modern Research in
} MANAGEMENT, ECONOMICS and ACCOUNTING

\author{
18-20 December, 2020 Oxford, United Kingdom
}

opportunity as well as a challenge for companies in building a brand. This is because time connectivity and relationships between consumers have been established freely and quickly with the internet. In the digital world, consumers can express and share opinions openly, like in blogs, commentary comments, social circles, and others. Consumers without fear often share stories on the internet about the good or bad of a brand (Kotler et al., 2017).

The important thing that should be done by marketers today is observing and learning consumer communication channels and consumer behavior. This is because consumers' buying intentions are no longer easily influenced by marketers and are no longer purely based on personal preferences. Marketing has now been more horizontal, namely consumers to consumers where consumers in choosing products are more interested in reading credible references and information from other consumers. This is alleged because consumers seem to protect themselves from their worries about brand fake claims and advertisement tricks by building a stronghold from their social circle (Kotler \& Keller, 2016). As a result, consumers prefer to follow the reference of friends who have experience buying these products in deciding and choosing a brand.

In consumer communication channels the concept of e-referral is different from e-WOM. This is because e-referrals are formed in smaller social groups with strong social ties and eWOM is formed in broad social groups with weak social ties. E-referrals occur in individuals who have strong social ties (Abubakar et al., 2016). Strong social ties as a form of e-referral shows how consumers' decisions follow group decisions because they have a sense of wanting to adjust to their social environment (Bagozzi, 2000).

The progress of the internet has caused WOM to be spread more widely and quickly. Modern WOM is often referred to as e-WOM or electronic word of mouth. E-WOM is a positive or negative statement made by current or previous consumers about a company's product or service, which is made for a large audience and can be accessed via the internet (Hennig-Thurau et al., 2004). E-WOM on the internet formed through product reviews that has a broad influence not only on consumer attitudes towards the brand image but also has an impact on their buying intentions (Kudeshia \& Kumar, 2017); (Windi \& Ellyawati, 2015). EWOM becomes an important factor that influences consumer behavior and consumer purchase intentions (Abubakar et al., 2016). This type of communication is considered to have great persuasion because of perceived credibility and trust (Chatterjee, 2001). The stronger credibility of reviews perceived by online consumers among potential customers will increase the consumer's purchase intention (Lee et al., 2011).

Creating and improving the brand image in marketing is very important for the company in retaining and gain new customers. Companies are required to actively observe consumer communication channels and behavior of internet users, so marketers can create or enhance brand images in the consumer's minds. The brand image reflects the quality of a product. Therefore, the better and the more positive the brand image can be a strong reason for consumers to be interested in buying the product.

\section{Theoretical Background and Hypothesis Development}

\section{Personal communication channels and non-personal communication channels}

A personal communication channel happens when two or more people are communicating directly with each other. Direct communication can be done face to face, via telephone, letter, 


\title{
$11^{\text {th }}$ International Conference on Modern Research in MANAGEMENT, ECONOMICS and ACCOUNTING
}

\author{
18-20 December, 2020 Oxford, United Kingdom
}

email, SMS (short message service), or social networking. Personal communication channels become effective because it allows people to get personal advice, preferences, and feedback from the person they are talking to. Some personal communication channels are controlled directly by the company. For example, the company's sales representatives. Other personal communications can reach buyers through channels and cannot be directly controlled by the company. These channels include neighbors, friends, family members, partners, or other consumers who talk and make an agreement with potential customers.

Personal communication channels give a big influence on consumers, especially when they buy expensive and risky products. A recent survey found that recommendations from friends and family have the most powerful influence on consumers around the world. More than $80 \%$ of consumers stated that friends and family are the most influential in their awareness and purchase. Another study found that $72 \%$ of consumers entrusted online reviews for getting information, while trust in advertising was less than $36 \%$ depending on the medium. So it is not surprising when many consumers more often look at online reviews to find out positive or negative responses from other consumer experiences (Kotler \& Armstrong, 2018).

Non-personal communication channels are media that carry messages without personal contact. The main media include print media (newspapers, magazines, direct letters), broadcast media (television, radio), screen media (billboards, posters), and online media (e-mails, corporate websites, and social networks, and online reviews). Non-personal communication is often used by marketers to stimulate personal communication by adding testimonials from other consumers in advertising a product or brand so that it can influence the purchase intentions of potential customers (Kotler \& Armstrong, 2018).

\section{Electronic referral (e-referral)}

A reference group is a person or group of people who have interacted face to face and have a direct influence in shaping one's attitude or behavior. Reference groups influence a person's attitude or behavior by creating pressure to adapt that can affect a person's product and brand choices (Kotler \& Armstrong, 2018). The consumer process of delivering a company's marketing message to friends, family members, and coworkers via online media is known as an e-referral. E-referral occurs when an individual has strong social ties in his/her online community (Abubakar et al., 2016). The rapid development of social media and interactive technology is driving e-referrals far more effective in online marketing than traditional marketing (Bataineh, 2015). E-referrals refer to positive online content about products/ brands that are obtained by consumers and then delivered to others using the internet (Mahapatra \& Mishra, 2017).

Compared to offline referral, e-referral tend to easily spread widely to consumers via the internet and cause a viral effect. Therefore, e-referral play an important role in the company's marketing performance (Zhang et al., 2018). A study conducted by (Bagozzi, 2000) found that strong social ties as a form of e-referral show how consumer purchasing decisions follow group decisions because they have a sense of wanting to adjust to their social environment. E-referral has a strong influence because the knowledge and experience of the previous consumer make this consumer tend to be an opinion leader and this can influence the behavior and buying interest of other consumers (Schreier et al., 2007). 


\title{
$11^{\text {th }}$ International Conference on Modern Research in
}

MANAGEMENT, ECONOMICS and ACCOUNTING

\author{
18-20 December, 2020 Oxford, United Kingdom
}

\section{Electronic word of mouth (e-WOM)}

E-WOM is a medium of communication for consumers to share information about products or services that have been purchased, used, or consumed, and amazingly these consumers may not know each other and have not met before (Gruen et al., 2006). The development of electronic media emerged as a strong and reliable source of information(Shukla, 2011). The influence of information sources (e-WOM) on purchase intentions has increased significantly (López \& Sicilia, 2014). E-WOM that have been published by the customer on social networks and the internet has a strong influence on brand image and influences buying interest (Jalilvand $\&$ Samiei, 2012).

Consumer purchasing decisions are influenced not only by the quantity of Word of mouth in various social media channels but also it's quality (Lin et al., 2013). The influence of information sources (e-WOM) on purchase intentions has increased significantly (López \& Sicilia, 2014). E-WOM on the internet that has product reviews have a broad influence not only on consumer attitudes towards brand image but also has an impact on consumer purchase intentions (Kudeshia \& Kumar, 2017).

E-WOM is an important element in increasing purchase intentions (Balakrishnan et al., 2014). (Lee et al., 2011) in their study stated that the stronger online consumer perceived credibility of reviews among potential consumers would increase the consumer's purchase intention. Besides, it is said that online consumer reviews positively influence purchase intentions. Reading reviews not only influences buyers' online purchasing decisions but also the frequency of their purchases (Yayli \& Bayram, 2012). E-WOM is an important element in creating purchase intentions (Balakrishnan et al., 2014).

\section{Brand image}

Brand image is defined as consumer perception of image and symbolic values inherent in a product and brand offered by the company (Schiffman \& Wisenblit, 2019a). The better and more positive the image of a product or brand, the more it will be remembered in the minds of consumers. To be successful in the market, companies must build a positive image from the beginning the company was founded (Chakraborty \& Bhat, 2018). A good brand image of a product will affect consumer purchase intentions (Abubakar et al., 2016).

\section{Purchase intention}

Purchase intention is an implicit promise to ourselves to buy a product in the future. Knowing purchase intention for a brand is very important because it illustrates the impression of consumers to the product (Tariq et al., 2013). Anggi \& Ellyawati (2015) stated that intention is one of the psychological aspects that can have a big influence on behavior. Intention to buy is one of the psychological aspects that arise from the feelings and thoughts about an item or service desired. Another person's attitude often becomes an intervention factor of a consumer buying decision. It also can reduce consumer preferences. The more intense the negative attitude of others towards a brand and the closer that person is to the consumer, the more likely the consumer is to ignore or divert his purchase intentions (Kotler \& Keller, 2016).

\section{Effect of e-referral on purchase intention}

Sources of information derived from relationships and strong social ties are considered more credible than other sources of information. A strong source of information will continue 


\title{
$11^{\text {th }}$ International Conference on Modern Research in MANAGEMENT, ECONOMICS and ACCOUNTING
}

\author{
18-20 December, 2020 Oxford, United Kingdom
}

to develop into a referral. Because of the tremendous development of internet media, it makes referrals are now easier to reach potential customers. With the presence of the internet, various media networks have emerged that can connect communication among consumers, and also known as e-referrals. The existence of e-referrals can influence the behavior and interests of consumers to buy a particular product or brand.

There is a tendency that prior consumer knowledge and experience drives it to be the opinion leader of a product or brand. Experienced consumers tend to give advice or information related to products that other consumers will buy based on their personal experience, and this can affect the behavior and buying interest of other consumers (Schreier et al., 2007). Sharing information and advice is usually done by consumers who have experiences of the closest social environment, such as friends, coworkers, family, and others. The environment and strong social ties are the main sources of influence, superior to external marketing communications, and even personal preferences. When consumers decide which brands to buy, there is a tendency that they follow the buying experience of their peers to avoid false brand claims and misleading advertisements by building strongholds from their social circle (Kotler \& Keller, 2016). E-referrals are more credible because sources of information are people who have strong social ties with potential customers. Based on this argument the hypothesis is proposed as follows:

H1: E-referral has a positive effect on purchase intentions

\section{Effect of e-referral on brand image}

Interaction among humans is now mostly facilitated by screens: smartphones, tablets, laptops, and television screens. Behind this screen-based interaction, the internet has become the backbone (Kotler \& Keller, 2016). The internet allows consumers to interact with other consumers about a brand easily. Consumers can share information to recommendations about a brand with relatives, family, and coworkers without limited time and place. This may also continue to occur repeatedly so that a strong bond on e-referrals will affect the brand image. Previous research conducted by (Abubakar et al., 2016) stated that e-referral is a key factor affecting the brand image from the consumer's point of view. Based on these argumentations, the proposed hypothesis is as follows:

H2: E-referral has a positive effect on brand image

\section{Effect of e-WOM on purchase intention}

The internet caused e-WOM to quickly spread widely throughout the world. The internet facilitates connectivity and relationships between consumers. Connectivity allows consumers to access information from various parties and can be used and experience to make better purchasing decisions (Kotler et al., 2017). The development of electronic media emerged as a powerful and reliable source of information (Shukla, 2011). The influence of information sources (e-WOM) on purchase intentions has increased significantly (López \& Sicilia, 2014). Research conducted by (Lee et al., 2011) found that the stronger perception of the credibility of reviews perceived by online consumers among potential consumers would increase the consumer's purchase intention. E-WOM is an important element in increasing purchase intentions (Balakrishnan et al., 2014). Based on the argumentations, we propose the following hypothesis:

H3: E-WOM has a positive effect on brand image 


\title{
$11^{\text {th }}$ International Conference on Modern Research in
}

MANAGEMENT, ECONOMICS and ACCOUNTING

\author{
18-20 December, 2020 Oxford, United Kingdom
}

\section{Effect of e-WOM on corporate image}

Internet advancements in the marketing era 4.0 make it even easier to connect between consumers. This has caused many consumers to care about the opinions of others. Previously consumers perceived a brand based solely on personal perceptions, which often differed from the image formed and projected by the company. On the internet, consumers communicate and share information with other consumers, talk about brands and companies. The internet has facilitated major changes by providing various platforms and communication tools (Kotler et al., 2017).

E-WOM is a positive or negative statement that is spread by current or previous consumers about a product, service, or company and can be accessed via the internet (Hennig-Thurau et al., 2004). Previous consumer review statements in the internet media regarding a product can be freely accessed by other consumers. Consumer reviews can also affect the brand image of a product. Moreover, the reviews and evaluation of information come from trusted consumers or previous customers (Jalilvand \& Samiei, 2012). A study conducted by (Abubakar et al., 2016) found that e-WOM is positively and significantly affects brand image. Based on this description the authors formulated the hypothesis as follows:

H4: E-WOM has a positive effect on brand image

\section{Effect of brand image on purchase intention}

For its products to be known to consumers, companies need to build a strong positive brand image and this must be a marketer priority goal (Chakraborty \& Bhat, 2018). According to (Kotler \& Armstrong, 2018), brand image is a set of trust that a brand has. A strong brand image on a product can increase the trust of prospective consumers of the product to be purchased. (Charo et al., 2015) stated that brand image has a positive effect on consumer purchase intentions. The better and more positive a brand image, the more it will be remembered in consumers' minds, and this can have a positive effect on the consumer's purchase intention (Abubakar et al., 2016). Based on this argument, we propose the following hypothesis:

H5: Brand image has a positive effect on purchase intentions

\section{Brand image mediates the relationship between e-referrals and purchase intention}

Sources of information obtained from the closest people including relatives, family, and coworkers in e-referral communication make the information considered more credible because the identity of the communicator is in the same social bond (Abubakar et al., 2016). E-referrals refer to positive online content about a product or brand, which is obtained and passed on by consumers to others using the internet (Mahapatra \& Mishra, 2017). Abubakar et al. (2016) stated that e-referral is a key factor affecting the brand image from the consumers' point of view. A strong brand image influences consumer purchase intentions and buying behavior and therefore companies need to have an advantage in the brand image of their products (Chakraborty \& Bhat, 2018). Based on these argumentations, we propose the hypothesis as follow:

H6: Brand image mediates the relationship between e-referrals and purchase intentions

\section{Brand image mediates the relationship between e-WOM and purchase intention}

E-WOM formed through product reviews from the internet, has a broad influence not only on consumer attitudes towards brand image but also has an impact on consumer purchase 


\section{$11^{\text {th }}$ International Conference on Modern Research in}

MANAGEMENT, ECONOMICS and ACCOUNTING

\section{8-20 December, 2020 Oxford, United Kingdom}

intentions (Kudeshia \& Kumar, 2017). (Lee et al., 2011) stated that the stronger perceived credibility of reviews perceived by online consumers among potential consumers will increase the consumer's purchase intention. A past study found that e-WOM has a significant positive effect on purchase intentions through brand image (Elseidi \& El-Baz, 2016) . Therefore, we propose the following hypothesis:

H7: Brand image mediates the relationship between e-WOM and purchase intentions

Figure 1: Research model

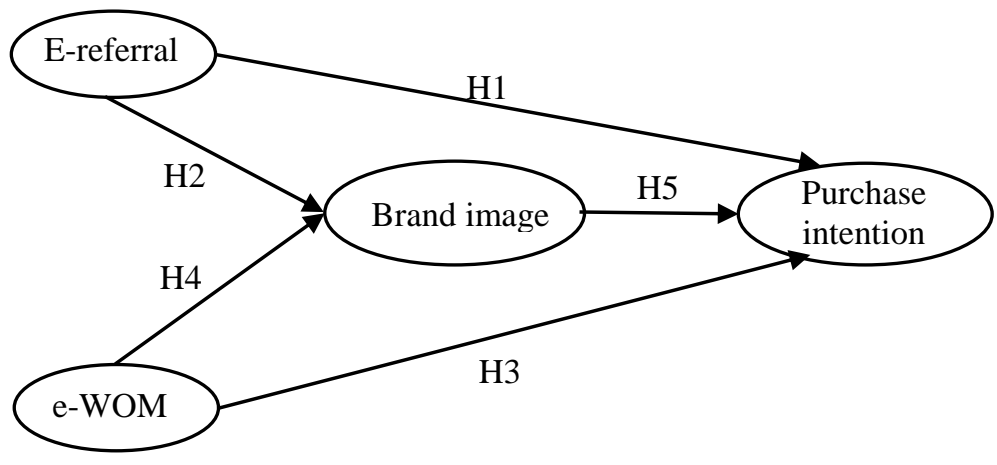

\section{Methodology}

The research object used in this study is the Asus brand. To collect data, this study employed a cross-sectional survey with a structured questionnaire. A total of 300 undergraduate students from various universities in Yogyakarta was recruited in this study using a non-probability sampling method with a purposive sampling technique. Data was collected through an online (158 respondents) and offline (142 respondents) survey. The questionnaire was measured using a 5-point Likert scale, from strongly agree (score 5) to strongly disagree (score 1). The research instrument was adopted from several previous studies and adjusted as needed. E-referral and brand image items adapted from (Abubakar et al., 2016), e-WOM from (Hennig-Thurau et al., 2004), and purchase intentions from (Anggi \& Ellyawati, 2015).

\section{Research procedure}

Firstly, research instrument was translate into Indonesian and then back translate into English. To have a good quality of data, we carried out face validity on research instruments. After having been revised several times and declared ready to distribute to respondents, a Google form and printed questionnaires were prepared. A pilot test was conducted by distributing questionnaires to 30 respondents. We employed the SPSS statistical program to process the validity and reliability of the research instrument. After all items of the research instrument were declared valid and reliable, we distributed questionnaires to all targeted respondents. The data obtained were then analyzed using SEM based on variants (PLS). Through PLS outer model and inner model were analyzed. 
$11^{\text {th }}$ International Conference on Modern Research in

MANAGEMENT, ECONOMICS and ACCOUNTING

\section{8-20 December, 2020 Oxford, United Kingdom}

\section{Analysis and Discussion}

\subsection{Respondent profile}

The respondent's ages ranged from 18 to 25 years, and 87 percent of them were between 20 to 22 years old. The respondents included women (51 percent) and men (49 percent). They are all undergraduate students from many universities in Yogyakarta region, Indonesia.

\subsection{Outer model (measurement model)}

Table 1 shows the outer loading value of each indicator ranging from 0.648 to 0.879 and AVE ranging from 0.583 to 0.785 . The measurement scales were found to be valid if the outer loading value exceeds the recommended threshold value of 0.6 and AVE 0.5 (Hair et al., 2014). The result of the outer model shows Cronbach's alpha of each construct ranging from 0.764 to 0.869 and $\mathrm{CR}$ ranging from 0.849 to 0,916 . The measurement scales were stated to be reliable if Cronbach's alpha and CR exceed the recommended threshold value of 0.7 (Hair et al., 2014).

Table 1: Outer Model

\begin{tabular}{|c|c|c|c|c|}
\hline Scale items & $\begin{array}{c}\text { Outer } \\
\text { Loadings }\end{array}$ & AVE & $\begin{array}{l}\text { Composite } \\
\text { Reliability }\end{array}$ & $\begin{array}{c}\text { Cronbach' } \\
\text { s Alpha } \\
\end{array}$ \\
\hline \multicolumn{5}{|l|}{ Electronic referral (e-ref): (Abubakar et al., 2016) } \\
\hline $\begin{array}{l}\text { I often buy product/brands referred by my friends, } \\
\text { colleagues and family }\end{array}$ & 0,770 & \multirow{4}{*}{0,583} & \multirow{4}{*}{0,849} & \multirow{4}{*}{0,764} \\
\hline $\begin{array}{l}\text { I often buy product/brands referred by trusted firms and } \\
\text { social network sites }\end{array}$ & 0,743 & & & \\
\hline $\begin{array}{l}\text { When I buy product/brands not referred I worry about my } \\
\text { decision }\end{array}$ & 0,782 & & & \\
\hline $\begin{array}{l}\text { Online referrals increase my confidence in purchasing a } \\
\text { product/brand }\end{array}$ & 0,759 & & & \\
\hline \multicolumn{5}{|c|}{ Electronic Word of Mouth (e-WOM): (Hennig-Thurau et al., 2004) } \\
\hline $\begin{array}{l}\text { I read an online review of Asus product/brand, to find out } \\
\text { whether Asus product/brand make a positive impression on } \\
\text { other consumers }\end{array}$ & 0,791 & \multirow{6}{*}{0,602} & \multirow{6}{*}{0,901} & \multirow{6}{*}{0,869} \\
\hline $\begin{array}{l}\text { Before buying an Asus product/brand, I read online reviews } \\
\text { from other consumers to ensure my choice was right }\end{array}$ & 0,790 & & & \\
\hline $\begin{array}{l}\text { I ask by online (through social networks, websites, blogs, } \\
\text { etc.) with other consumers to help choose the right Asus } \\
\text { product/brand }\end{array}$ & 0,729 & & & \\
\hline $\begin{array}{l}\text { I gather information from other consumer reviews before I } \\
\text { buy an Asus product/brand }\end{array}$ & 0,800 & & & \\
\hline $\begin{array}{l}\text { I am worried about my decision to buy Asus product/brand if } \\
\text { I don't read online reviews from other consumers } \AA\end{array}$ & 0,752 & & & \\
\hline $\begin{array}{l}\text { When I buy Asus product/brand, online reviews from other } \\
\text { consumers make me confident to buy Asus product/brand }\end{array}$ & 0,791 & & & \\
\hline \multicolumn{5}{|l|}{ Brand Image (BI): (Abubakar et al., 2016) } \\
\hline $\begin{array}{l}\text { In comparison to other products/brands, Asus product/brand } \\
\text { has high quality }\end{array}$ & 0,801 & \multirow{4}{*}{0,625} & \multirow{4}{*}{0,868} & \multirow{4}{*}{0,798} \\
\hline Asus product/brand has a good reputation & 0,648 & & & \\
\hline I can reliably predict how Asus product/brand will perform & 0,843 & & & \\
\hline & 0,854 & & & \\
\hline
\end{tabular}


$11^{\text {th }}$ International Conference on Modern Research in

MANAGEMENT, ECONOMICS and ACCOUNTING

\section{8-20 December, 2020 Oxford, United Kingdom}

\begin{tabular}{|c|c|c|c|c|}
\hline \multicolumn{5}{|l|}{ Purchase Intention (PI): (Anggi and Ellyawati, 2015) } \\
\hline $\begin{array}{l}\text { I prefer to choose Asus product/brand to other available } \\
\text { products/brands }\end{array}$ & 0,879 & \multirow{3}{*}{0,785} & \multirow{3}{*}{0,916} & \multirow{3}{*}{0,863} \\
\hline I am willing to recommend others to buy Asus product/brand & 0,868 & & & \\
\hline I intend to buy an Asus product/brand in the future & 0,911 & & & \\
\hline
\end{tabular}

To test discriminant validity, we compared the value of the cross-loading factor of an indicator to the values of the cross-loading factor of other constructs' indicator. An indicator is stated valid if it has the highest loading factor to the intended construct compared to the loading factor to other constructs. Based on that criterion, it can be concluded that all indicators are stated valid because each indicator in this study has the highest loading factor to the intended construct compared to the loading factor to other constructs.

\subsection{Inner Model}

Hypothesis testing in this study can be seen from the direction of the value of the original sample estimate $(\beta)$, t-statistic, and p-value.

Table 2: Path Coefficients - SEM-PLS Bootstrapping

\begin{tabular}{|c|l|c|c|c|l|}
\hline $\begin{array}{c}\text { Hypothesis } \\
\text { no. }\end{array}$ & $\begin{array}{l}\text { Hypothesized } \\
\text { Effect }\end{array}$ & $\begin{array}{c}\text { Original } \\
\text { Sample }(\boldsymbol{\beta})\end{array}$ & t-stat & p-value & Decision \\
\hline H1 & e-Ref -> PI & 0,200 & 3,591 & 0,001 & Supported \\
\hline H2 & e-Ref -> BI & 0,395 & 7,553 & 0,000 & Supported \\
\hline H3 & e-WOM -> PI & 0,125 & 2,032 & 0,043 & Supported \\
\hline H4 & e-WOM -> BI & 0,199 & 3,246 & 0,001 & Supported \\
\hline H5 & BI -> PI & 0,433 & 7,015 & 0,000 & Supported \\
\hline
\end{tabular}

Table 2 shows that e-referral positively and significantly influences on purchase intention $(\beta=+0.200 ; t>1.96 ; p$-value $<0.05)$. With a level of confidence of $95 \%$, the $t$-table is 1.96 . Ereferral also has a positive and significant effect on brand image $(\beta=+0.395 ; \mathrm{t}>1.96$; $\mathrm{p}$ value $<0)$. Meanwhile, e-WOM has a positive and significant effect on purchase intention $(\beta=+0.125 ; \mathrm{t}>1.96 ; \mathrm{p}$-value $<0.05)$. E-WOM has a positive and significant effect on the brand image $(\beta=+0.199 ; t>1.96 ; p$-value $<0.05)$ and brand image has a positive and significant effect on purchase intention $(\beta=+0.433 ; \mathrm{t}>1.96$; $\mathrm{p}$-value $<0.05)$. Thus based on the $\mathrm{t}$-test, hypotheses $\mathrm{H} 1, \mathrm{H} 2, \mathrm{H} 3, \mathrm{H} 4$, and $\mathrm{H} 5$ are supported.

Coefficient of determination (R-square) is used to predict and measure how much the contribution of the influence of the independent variable on the dependent variable simultaneously. Based on PLS output it is known that brand image is influenced by e-referral and e-WOM simultaneously by $23.8 \%\left(\mathrm{R}^{2}=0.238\right)$, while the remaining is influenced by other variables not included in the model. The e-referral and e-WOM simultaneously influence purchase intention by $36.8 \%\left(\mathrm{R}^{2}=0.368\right)$ and the remaining is influenced by other variables not included in the model. 


\section{$11^{\text {th }}$ International Conference on Modern Research in}

MANAGEMENT, ECONOMICS and ACCOUNTING

\section{8-20 December, 2020 Oxford, United Kingdom}

\section{Testing mediating variable}

Table 3 shows that e-referral influences significantly on purchase intention with $(\beta=+$ $0.200 ; \mathrm{t}>1.96 ; \mathrm{p}$-value $<0.05(\mathrm{p} 3)$. E-referral effect significantly on purchase intention indirectly through brand image $(\beta=0.171$; t-statistic $>1.96$; $p$-value $<0.05)$. While total effect of e-referral on purchase intention mediated by brand image is significant $(\beta=+0.371 ; \mathrm{t}>1.96$; $\mathrm{p}$ value $<0.05)$. Because (p1 x p2), (p3) and (p1 x p2) + (p3) are all significant, it can be concluded that the mediating effect occurs is complementary partial mediation (H6 supported).

Table 3: Direct Effect, Indirect Effect, and Total Effect of E-Referral, Brand image, and Purchase Intention

\begin{tabular}{|l|l|c|c|c|c|}
\hline Phase & Indep var $\rightarrow$ Dep var & $\begin{array}{l}\text { Original } \\
\text { Sample }(\beta)\end{array}$ & t-statistic & p-value & Decision \\
\hline Direct effect (p1) & E-Ref $\rightarrow$ BI & 0,395 & 7,553 & 0,000 & Significant \\
\hline Direct effect (p2) & BI $\rightarrow$ PI & 0,433 & 7,015 & 0,000 & Significant \\
\hline Direct effect (p3) & E-Ref $\rightarrow$ PI & 0,200 & 3,591 & 0,000 & Significant \\
\hline Indirect effect (p1 x p2) & E-Ref $\rightarrow$ PI & 0,171 & 5,292 & 0,000 & Significant \\
\hline Total effect (p1 x p2) + p3 & E-Ref $\rightarrow$ PI & 0,371 & 6,792 & 0,000 & Significant \\
\hline
\end{tabular}

Table 4: Direct Effect, Indirect Effect, and Total Effect of E-Referral, Brand image, and Purchase intention

\begin{tabular}{|l|l|c|c|c|c|}
\hline Phase & Indep var->Dep var & $\begin{array}{c}\text { Original } \\
\text { Sample }(\beta)\end{array}$ & t-statistic & p-value & Decision \\
\hline Direct effect (p1) & e-WOM -> BI & 0,199 & 3,246 & 0,001 & Significant \\
\hline Direct effect (p2) & BI-> PI & 0,433 & 7,015 & 0,000 & Significant \\
\hline Direct effect (p3) & e-WOM -> PI & 0,125 & 2,032 & 0,043 & Significant \\
\hline Indirect effect (p1 x p2) & e-WOM -> PI & 0,086 & 2,880 & 0,004 & Significant \\
\hline Total effect (p1 x p2) + p3 & e-WOM -> PI & 0,211 & 3,691 & 0,000 & Significant \\
\hline
\end{tabular}

Table 4 shows that e-WOM influences significantly on purchase intention with $(\beta=+0.125$; $\mathrm{t}>1.96$; p-value $<0.05(\mathrm{p} 3)$. E-WOM effect significantly on purchase intention indirectly through brand image $(\beta=0,086 ; \mathrm{t}$-statistic $>1.96 ; \mathrm{p}$-value $<0.05)$. While total effect of e-WOM on purchase intention mediated by brand image is significant $(\beta=+0,211 ; t>1.96 ; p$-value $<0.05)$. Because (p1 x p2), (p3) and (p1 x p2) + (p3) are all significant, it can be concluded that the mediating effect occurs is complementary partial mediation (H7 supported).

\subsection{Discussion and Conclusion}

This study found the increment of e-referral activities tend to increase brand image and consumer purchase intentions. The reason consumers buy products is that they get referrals from friends, colleagues, family, or companies that are trusted through social networks or with other online media. People who get positive recommendations tend to have a good image of products and will be interested in purchasing the recommended product in the future, and will even recommend it to other consumers.

The study also found that consumer's purchase intention is influenced by their closest social ties. Consumers tend to be more confident in choosing products that are referred to or recommended by their closest social ties than products with other available brands. Instead, the consumer will feel doubtful when buying a product without any recommendations or referrals from the closest social ties. This study supports the study conducted by (Schreier et al., 2007) which states that e-referrals have a strong influence because the knowledge and experience of 


\title{
$11^{\text {th }}$ International Conference on Modern Research in MANAGEMENT, ECONOMICS and ACCOUNTING
}

\author{
18-20 December, 2020 Oxford, United Kingdom
}

previous consumers make past consumers tend to be opinion leaders and can influence the buying behavior and interest of others.

The results of this study contradict a study conducted by (Abubakar et al., 2016). In his research stated that e-referral does not affect purchase intentions. While studies conducted by (Steffes \& Burgee, 2009) show that referrals can have a positive or negative effect on purchase intentions, and even have no effect. This is caused by the factor of sample and research object used in the research. Sample factors such as personality, social environment, and trust greatly influence the acceptance of recommendations. Positive or negative product perceptions that are spread in a social environment can be different, furthermore will certainly have different results in influencing consumer purchase intentions.

This study found that e-WOM had a positive effect on brand image and purchase intention. The study also found that the effect of e-referrals on purchase intentions was greater than the effect of e-WOM on purchase intentions. The lack of consumer confidence regarding the credibility of e-WOM information such as online reviews, blogs, websites, or other online media so that consumers ignore or divert their purchase intentions. Lack of trust in information sources on e-WOM will greatly affect consumer purchase intentions (López \& Sicilia, 2014). Besides this, the quality of information on e-WOM greatly influences consumer purchasing decisions (Lin et al., 2013). Therefore, this study confirms previous studies that e-WOM had a positive and significant effect on purchase intention (Elseidi \& El-Baz, 2016); (Farzin \& Fattahi, 2018).

This study found that e-WOM had a positive and significant effect on brand image. The result of this study stated that the effect of e-WOM is greater on brand image than purchase intention. While a study conducted by (Balakrishnan et al., 2014) stated that e-WOM has a broad influence on consumer attitudes and brand image. The study confirms previous studies that e-WOM has a positive and significant effect on the brand image (Abubakar et al., 2016); (Kudeshia \& Kumar, 2017).

When a product has a good brand image that includes perceived quality, reputation, and product performance excellence and is trusted by consumers, it will increase consumer's current purchase intentions and future purchase intention or even be willing to recommend these products to other potential customers. Thus the better and more positive a brand image will be remembered in the minds of consumers. This is in line with studies conducted by (Abubakar et al., 2016) that stated a strong brand image tends to influence buying intentions and consumer behavior. Therefore, companies need to have brand excellence to increase consumer purchase intentions (Chakraborty \& Bhat, 2018). Thus the results of this study confirm previous research results that brand image has a positive and significant effect on purchase intentions (Charo et al., 2015);(Abubakar et al., 2016);(Chakraborty \& Bhat, 2018).

The effect of complementary partial mediation of brand image through e-referral compared to complementary partial mediation of brand image through e-WOM on purchase intention can be determined through the total effect of each independent variable. The e-referral variable has a greater total effect than the e-WOM variable so it can be concluded that the brand image has a higher mediating effect through e-referral and purchase intentions than through e-WOM and purchase intention. Both e-referral and e-WOM have a direct effect on purchase intention and an indirect influence through the brand image, however, the influence of e-referral is greater than e-WOM. 


\title{
$11^{\text {th }}$ International Conference on Modern Research in MANAGEMENT, ECONOMICS and ACCOUNTING
}

\author{
18-20 December, 2020 Oxford, United Kingdom
}

\section{Limitation and Future Research}

This study used the electronic product Asus brand as a research object. Each product category has its characteristics, so this study cannot be generalized to other products. We suggest that future research can broaden the research object by using a different category of brands or products. Secondly, this study employed undergraduate students as respondents. As we know that this level of age belongs to the $\mathrm{z}$ generation (Schiffman \& Wisenblit, 2019b), which is a digital generation that is very proficient in information technology and various computer applications. They often shop through online applications, thus they are very familiar with social e-referral and e-wom. Thus, this study cannot be generalized to other age levels. For future research, respondents recruited should use a more diverse range of ages. Thirdly, this study only used e-referral and e-WOM variables in predicting brand image and purchase intention. There are still many other variables that affect brand image and purchase intention. For future research, it is suggested to consider other variables such as country of origin, celebrity endorser, viral marketing, and culture.

\section{REFERENCES}

Abubakar, A. M., Ilkan, M., \& Sahin, P. (2016). eWOM, eReferral and gender in the virtual community. Marketing Intelligence and Planning, 34(5), 692-710. https://doi.org/10.1108/MIP-05-2015-0090

Anggi, C., \& Ellyawati, J. (2015). Effect of Consumer Etnocentrism On the Intention to Buy Notebook Products: Testing Perceived Quality as Mediator (in Bahasa). E-Journal. Uajy. Ac. Id, 1-14. https://scholar.google.co.id/citations?user=H9YCus0AAAAJ\&hl=id

Bagozzi, R. P. (2000). On the concept of intentional social action in consumer behavior. Journal of Consumer Research, 27(3), 388-396. https://doi.org/10.1086/317593

Balakrishnan, B. K. P. D., Dahnil, M. I., \& Yi, W. J. (2014). The Impact of Social Media Marketing Medium toward Purchase Intention and Brand Loyalty among Generation Y. Procedia - Social and Behavioral Sciences, 148, 177-185. https://doi.org/10.1016/j.sbspro.2014.07.032

Bataineh, A. Q. (2015). The Impact of Perceived e-WOM on Purchase Intention: The Mediating Role of Corporate Image. International Journal of Marketing Studies, 7(1), 126-138. https://doi.org/10.5539/ijms.v7n1p126

Chakraborty, U., \& Bhat, S. (2018). Credibility of online reviews and its impact on brand image. Management Research Review, 41(1), 148-164. https://doi.org/10.1108/MRR-06-2017-0173

Charo, N., Sharma, P., Shaikh, S., Haseeb, A., \& Sufya, M. Z. (2015). Determining the impact of eWOM on brand image and purchase intention through adoption of online opinions. International Journal of Humanities and Management Sciences, 3(1), 41-46. http://www.isaet.org/images/extraimages/P115054.pdf

Chatterjee, P. (2001). Online Reviews : Do Consumers Use Them? Advances in Consumer Research. Association for Consumer Research (U.S.), 129-134.

Elseidi, R. I., \& El-Baz, D. (2016). Electronic word of mouth effects on consumers' brand attitudes, brand image and purchase intention: an empirical study in Egypt. The Business and Management Review, 7(5).

Farzin, M., \& Fattahi, M. (2018). eWOM through social networking sites and impact on purchase intention and brand image in Iran. Journal of Advances in Management Research, 15(2), 161183. https://doi.org/10.1108/JAMR-05-2017-0062

Gruen, T. W., Osmonbekov, T., \& Czaplewski, A. J. (2006). eWOM: The impact of customer-to- 


\title{
$11^{\text {th }}$ International Conference on Modern Research in MANAGEMENT, ECONOMICS and ACCOUNTING
}

\author{
18-20 December, 2020 Oxford, United Kingdom
}

customer online know-how exchange on customer value and loyalty. Journal of Business Research, 59(4), 449-456. https://doi.org/10.1016/j.jbusres.2005.10.004

Hair, J. F. J., Black, W. C., Babin, B. J., \& Anderson, R. E. (2014). Multivariate Data Analysis (7th ed.).Edinburgh Gate, Harlow: UK: Pearson Education Limited. www.pearsonedco.uk

Hennig-Thurau, T., Gwinner, K. P., Walsh, G., \& Gremler, D. D. (2004). Electronic word-of-mouth via consumer-opinion platforms: What motivates consumers to articulate themselves on the Internet? Journal of Interactive Marketing, 18(1), 38-52. https://doi.org/10.1002/dir.10073

Jalilvand, M. R., \& Samiei, N. (2012). The effect of electronic word of mouth on brand image and purchase intention: An empirical study in the automobile industry in Iran. Marketing Intelligence and Planning, 30(4), 460-476. https://doi.org/10.1108/02634501211231946

Kotler, P., \& Armstrong, G. (2018). Principles of Marketing (17th ed.). Harlow, UK: Pearson Education Limited. www.pearsonglobaleditions.com

Kotler, P., Kartajaya, H., \& Setiawan, I. (2017). Marketing 4.0: Moving from Traditional to Digital $\left(1^{\text {st }}\right)$. Hoboken, New Jersey, USA: John Wiley \& Sons, Inc. http://booksupport.wiley.com

Kotler, P., \& Keller, K. L. (2016). Marketing Management (15e ed.). Edinburgh Gate, Harlow, UK: Pearson Education Limited. www.pearsonglobaleditions.com

Kudeshia, C., \& Kumar, A. (2017). Social eWOM: does it affect the brand attitude and purchase intention of brands? Management Research Review, 40(3), 310-330. https://doi.org/10.1108/MRR-07-2015-0161

Lee, J., Park, D. H., \& Han, I. (2011). The different effects of online consumer reviews on consumers' purchase intentions depending on trust in online shopping malls: An advertising perspective. Internet Research, 21(2), 187-206. https://doi.org/10.1108/10662241111123766

Lin, C., Wu, Y.-S., \& Chen, J.-C. V. (2013). Electronic Word-of-Mouth: The Moderating Roles of Product Involvement and Brand Image. International Conference on Technology Innovation and Industrial Management, 29-47.

López, M., \& Sicilia, M. (2014). Determinants of e-WOM influence: The role of consumers' internet experience. Journal of Theoretical and Applied Electronic Commerce Research, 9(1), 28-43. https://doi.org/10.4067/S0718-18762014000100004

Mahapatra, S., \& Mishra, A. (2017). Acceptance and forwarding of electronic word of mouth. Marketing Intelligence and Planning, 35(5), 594-610. https://doi.org/10.1108/MIP-01-2017-0007

Schiffman, L. G., \& Wisenblit, J. (2019). Consumer Behavior (12th ed.). Harlow, UK: Pearson Education Limited.

Schreier, M., Oberhauser, S., \& Prügl, R. (2007). Lead users and the adoption and diffusion of new products: Insights from two extreme sports communities. Marketing Letters, 18(1-2), 15-30. https://doi.org/10.1007/s11002-006-9009-3

Shukla, P. (2011). Impact of interpersonal influences, brand origin and brand image on luxury purchase intentions: Measuring interfunctional interactions and a cross-national comparison. Journal of World Business, 46(2), 242-252. https://doi.org/10.1016/j.jwb.2010.11.002

Steffes, E. M., \& Burgee, L. E. (2009). Social ties and online word of mouth. Internet Research, 19(1), 42-59. https://doi.org/10.1108/10662240910927812

Tariq, M. I., Rafay Nawaz, M., Nawaz, M. M., \& Butt, H. A. (2013). Customer Perceptions about Branding and Purchase Intention: A Study of FMCG in an Emerging Market. J. Basic. Appl. Sci. Res, 3(2), 340-347.

Windi, \& Ellyawati, J. (2015). Trust, Antecedent and Consequence in Online Shopping Context: Testing The Role of e-WOM as Moderating Effect. International Journal of Management and Applied Science, 1(5).

Yaylí, A., \& Bayram, M. (2012). e-WOM: The effects of online consumer reviews on purchasing decisions. International Journal of Internet Marketing and Advertising, 7(1), 51-64. https://doi.org/10.1504/IJIMA.2012.044958 
$11^{\text {th }}$ International Conference on Modern Research in MANAGEMENT, ECONOMICS and ACCOUNTING

\section{8-20 December, 2020 Oxford, United Kingdom}

Zhang, D., Zhang, F., Liu, S., \& Du, H. S. (2018). Impact of referral reward program on innovative customers' follow-up e-referral: The moderating role of creative self-efficacy. Information Technology and People, 32(3), 559-578. https://doi.org/10.1108/ITP-06-2017-0188 